\title{
1. Is it necessary to have Islamic economics?
}

If Islam can be shown to be capable of providing fruitful vision to illuminate the modern conscience, then all mankind and not only Muslims, have a stake in the outcome. (Marshall Hodgson, 1977, Vol. 3, p. 441)

Apart from the Islamic world, where fundamentalist political tendencies are quite marked, the global political scene is dominated by rhetoric and values that are primarily consumption-oriented and that stress personal selfgratification as the primary purpose of political action.

(Zbigniew Brzezinsky, 1995, p. 53)

\subsection{INTRODUCTION}

Conventional economics, which dominates modern economic thinking, has become a well-developed and sophisticated discipline after going through a long and rigorous process of development over more than a century. The development continues uninterrupted, as reflected in the publication of innumerable journals, books, and research reports throughout the world. Individuals, universities, research organizations, and governments are all participating actively in this development. As a result of accelerated development in Western industrial countries over a long period, substantial resources are available to scholars to pursue their research. It goes to the credit of the West that there is a great quest for knowledge; researchers are willing to work rigorously, and creative work gets richly rewarded in terms of both prestige and material benefits.

Islamic economics has, however, had its resurgence only over the last three to four decades. The number of individuals, universities, governments, and research organizations participating in its development is relatively very small. Since most Muslim countries are poor and in the initial stage of development, the resources they have available at their disposal for financing research activities are also relatively meagre. Moreover, some of the governments in Muslim countries consider the resurgence of Islam, with its unmistakable call for political accountability and socio-economic justice, to be a threat to their survival. They are, 
therefore, reluctant to render any moral or material support for the development of Islamic social sciences.

An unavoidable question, therefore, is whether it is really necessary to have Islamic economics when conventional economics is already there in a highly developed form. This question acquires particular significance because the subject matter of both disciplines is nearly the same: allocation and distribution of scarce resources among their infinite uses. The justification would be there only if the effort to develop Islamic economics is directed toward the realization of a purpose that cannot be realized by the analysis developed by conventional economics. The need would be all the more acute if the set of variables employed for the analysis is broader, and the mechanisms and method to be used for the allocation and distribution of resources are also different.

\subsection{THE VISION}

Every activity of rational human beings generally has a purpose, and it is usually the purpose that determines its nature, differentiates it from other activities, and also helps evaluate its performance. The first question that one may, therefore, wish to ask is about the purpose behind studying the allocation and distribution of resources. Such a study may not have been necessary if resources were unlimited. However, resources are limited and not sufficient to satisfy all the claims on them by all individuals and groups in society. We are, therefore, posed with the perplexing question of which uses and whose claims to choose and how to make the choice. A simple answer may perhaps be to use them in a way that would help the society realize its vision. A vision essentially incorporates the dream of a society about what it would like to be in the future. It may consist of a number of goals, which the society aspires to achieve. All of these goals may together serve as a guiding star and indicate the direction in which the society wishes to proceed. This may help channel the society's efforts and energies in the desired direction and thereby minimize waste. The vision may never be fully realized. It may, nevertheless, continue to inspire the society to persist in the struggle for its realization by keeping the faith in the future perennially kindled.

Different societies may have different visions. Nevertheless, there is one dimension that seems to be common among the visions of most societies. This is the goal of realizing human well-being. However, the term well-being, even though used by a number of economists (Oswald et al., 1997) is itself a controversial term and may be defined in a number of ways. It may be defined in a purely material sense, totally ignoring its 
spiritual content, or in a way that also takes into account the spiritual aspect. Depending on which definition of well-being one adopts, there may arise the need for an entirely different configuration of goods and services to be produced by the society with the scarce resources at its disposal. This may lead to different mechanisms for allocation and distribution.

If well-being were to be defined in a purely material and hedonist sense, then it would be perfectly rational for economics to give prominence to the serving of self-interest and the maximization of wealth, bodily pleasures, and sensual satisfactions. Because pleasures and sensual satisfactions depend primarily on individual tastes and preferences, value judgments may have to be kept out to allow individuals total freedom to decide for themselves what they wish. All goods and services that provide bodily pleasures and sensual satisfactions to individuals in accordance with their own tastes and preferences may become acceptable. The impartial market forces may then be considered sufficient to bring about such an allocation and distribution of resources. Redistribution $^{1}$ of the wealth produced may be important, but only to the extent to which it does not interfere with the freedom of the individual to pursue his/her self-interest. The government's role may also have to be kept at a minimum, except to the extent to which it is necessary to enable the individual and the market to perform effectively.

However, if well-being were to be defined in a way that rises above the materialist and hedonist sense and incorporates humanitarian and spiritual goals, then economics may not be able to avoid a discussion of what these goals are and how they may be realized. These goals may include not only economic well-being, but also human brotherhood and socioeconomic justice, mental peace and happiness, and family as well as social harmony. One of the tests for the realization of these goals may be the extent to which social equality, need-fulfilment of all, full employment, equitable distribution of income and wealth, and economic stability have been attained without heavy debt-servicing burden, high rates of inflation, undue depletion of nonrenewable resources, or damage to the ecosystem in a way that endangers life on earth. Another test may be the realization of family and social solidarity, which would become reflected in the mutual care of members of the society for each other, particularly the children, the aged, the sick, and the vulnerable, and absence, or at least minimization, of broken families, juvenile delinquency, crime, and social unrest.

Once economics gets into a discussion of human well-being in this comprehensive sense, then the task of economics may become wider and more difficult and complex. It may not be able to confine itself to just 
economic variables. It may have to take into account all those factors, including moral, psychological, social, political, demographic and historical, that determine well-being in this comprehensive sense. It may also have to answer a number of questions that may not need an answer if its goal were only to help maximize wealth and consumption. One of these questions may be about whether the serving of self-interest would be sufficient as a motivating force to realize comprehensive well-being, or would it also be necessary to have some other motivating force. Could such well-being be realized more effectively if all the agents operating in the market observed certain rules of behaviour and had certain desirable qualities? If so, then it may be necessary to impose certain constraints on individual behaviour. The individual may not then remain totally free to do what he/she pleases in accordance with his/her tastes and preferences. The question that would then arise is about who will determine these constraints, and how would it be ensured that the individual's freedom is not unduly restricted. This is because individual freedom is also essential for human well-being and cannot be compromised except to a certain agreed extent.

In addition, there are a number of institutions in human society that influence individual and social outcomes. The market is only one of them. Some others are family, society, and the state. Family may perhaps be the most important of these because it provides the human input for the market, the society, and the state. It is the primary breeding place and training ground for all individuals. It is here that a substantial part of individual tastes and preferences, personalities, and behaviour patterns get formed. The family's health and solidarity would hence be of crucial importance. If the family disintegrates, would it be possible to provide the future generation with the kind of upbringing that it needs? If the quality of upbringing goes down, then it may not be possible for a society to sustain its development and supremacy for long in the economic, technological, or military fields. Because economics is also concerned with the rise and fall of a society, then would it be realistic on its part to ignore the integrity and stability of the family?

If the market, the family, the society, and the state all have a role to play in human well-being, then the question is how to make them play their roles in a manner that complements and does not hinder the effective performance of their role by others? Although the market may operate efficiently if every individual tries to serve his/her self-interest, would it also be possible for families, the society, and the state to operate effectively and harmoniously if everyone were to behave in the same self-interested manner? 
These are not new questions. They have been addressed by social philosophers for centuries. The majority seems to hold the view that the serving of self-interest is only one of the motivating forces in human society, and maximization of wealth and consumption is only one of the goals. The spiritual and humanitarian goals stated above are of equal, if not greater importance. Some of these goals may in fact be in conflict with each other, and a compromise may need to be struck. Would it be possible for a society to arrive at such a compromise if it sets maximization of wealth and consumption as its primary goal, and its members are not willing to sacrifice their self-interest for realizing the society's humanitarian goals?

Sacrifice is of particularly great importance in the case of the family and the society. Experience shows that the more the parents are attached to each other and adopt an attitude of mutual sacrifice and cooperation, the greater harmony and stability is likely to be there in the family. The upbringing of children also requires a substantial degree of mutual cooperation and sacrifice of self-interest on the part of parents. Similarly social harmony may also require members to cooperate with each other and to sacrifice for the common good and to take care of the poor and the vulnerable. Even in the case of the market and the state, sacrifice may not be avoidable. In spite of competition, which helps safeguard social interest, it may be possible for operators in the market to make unjustified gains by cheating and obstructing competition in a manner that may be difficult to detect. Similarly, although democracy, public accountability, and a free press do help in protecting the public interest, it may nevertheless be possible for government officials to use their authority for personal benefit at the expense of the taxpayer.

Therefore, there has to be some motivating force that prevents individuals from wrongdoing even when it is possible for them to get away unscathed. Government coercive power has proved to be an effective motivating force. However, if this were the only force in human society to prevent wrongdoing, the costs of enforcement may tend to be very high. Is it possible to supplement competition, public accountability, and government coercive power by some other motivating force that might induce members of society to abide willingly to agreed values or rules of behaviour and to fulfil their contracts and social obligations faithfully even when this involves a sacrifice of self-interest?

This brings us to the question of why should any person sacrifice his/her self-interest to serve social interest in the market place, the family, the society, or the government. If economics concentrates only on self-interest and has no place for a motivating force other than selfinterest, then it may not be able to answer this question. If maximizing 
wealth and consumption is the only goal in the life of an individual, then there is no need to make any sacrifice for others. Serving self-interest may be the best policy. The family may then suffer; the quality of the future generation may decline, and even the performance of the market and the government may ultimately be adversely affected. The question, therefore, is how to motivate individuals to fulfil their contracts and other commitments honestly and not to undermine competition or to resort to unfair means of earning, even when it is possible for them to get away with it? This is a question that religions have tried to address by providing rules of behaviour in the form of moral obligations of individuals towards other human beings, animals, and the environment and trying to motivate their followers to abide by these rules even when doing so hurts their self-interest in this world. Whether or not they have succeeded in this task is a different matter. However, economics may not be able to ignore religious values and the associated motivating force if its goal is the realization of comprehensive well-being.

A society may have attained the pinnacle of glory in the material sense, but it may not be able to sustain it for long if the moral fibre of individuals and society is weakening, the family is disintegrating, the new generation is unable to get the kind of attention and upbringing that are necessary for an achieving civilization, and social tensions and anomie are rising. The material and the spiritual aspects of well-being are not, therefore, independent of each other. They are closely interrelated. Greater family harmony may help raise better individuals to operate in the market, and better social harmony may create a more conducive environment for effective government and accelerated development. If this is true, then the emphasis on serving self-interest and maximizing wealth and consumption may have to be toned down to some extent to serve social interest and optimize human well-being. Some uses of resources that serve self-interest and fit well into the hedonist framework may have to be reduced to fulfil the needs of all individuals in society and thereby promote family and social harmony.

Available evidence supports the contention that material advance is not by itself sufficient to increase happiness and social harmony. 'Rich countries are not typically happier than poor countries', concludes Richard Easterlin after 30 surveys conducted in 19 developed and developing countries (Easterlin, 1973, 1995; Oswald, 1997). There is something else that is also needed to create happiness and harmony and to remove tensions and anomie. Therefore, if economics concerns itself with well-being in its comprehensive sense, then it may not be able to confine its discussion to just material prosperity. ${ }^{2}$ 


\subsection{THE MECHANISMS}

How human well-being is defined is, therefore, an extremely crucial factor in the allocation and distribution of resources. If there is a difference in the concept of well-being, then there will also be a difference in the mechanisms and method for realizing it. There are three important mechanisms that determine the use of resources in any society or economic system. These are filtering, motivation, and socio-economic and political restructuring (Chapra, 1992, pp. 213-33). Just as it is possible to define well-being in a number of ways, it is also possible to have different mechanisms for filtering, motivation, and socio-economic restructuring.

First, all the different claims on limited resources need to be passed through a filter, in a way that realization of spiritual or humanitarian goals is not jeopardized, to create equilibrium between all the claims on these resources and their supply. There may be different ways of filtering. Three of these are central planning, market mechanism, and moral values (Chapra, 1992, pp. 71-112). Experience of socialist countries has shown that central planning is not an effective mechanism for filtering, even in the material sense, and almost all of them have abandoned it by now, except perhaps Cuba. However, market mechanism has performed extremely well. Prices determined through the interaction of supply and demand in perfectly competitive markets help filter out the various uses of resources in a way that equilibrium gets established. But the problem with the use of market mechanism for filtering is that it is possible to have several market equilibria depending on which tastes and preferences of individuals and firms interact with each other in the market place. Any and every market equilibrium may not lead to the realization of humanitarian goals. It may be desirable to complement the market system by some other mechanism that would help change individual tastes and preferences in a way that would lead to the desired kind of equilibrium. Could moral values help bring about such a change?

Second, if coercion is ruled out, then the desired kind of filtering may have to be brought about by motivating all individuals sufficiently to put in their best performance and to abstain from the use of resources in a way that frustrates the realization of the desired kind of well-being. Motivation acquires a great significance in economics as compared with, say physics, because economics deals with human beings who may or may not always behave in a standard manner that would be conducive to goal realization. The serving of self-interest has proved to be an effective motivating mechanism for increasing efficiency, whereas competition, 
public accountability, and government intervention have helped safeguard social interest. Would it be possible to safeguard social interest even more effectively if both market mechanism and government intervention are complemented by a sense of moral obligation?

Third, the physical, social, and political environments also influence human behaviour and the use of scarce resources. It may hence be necessary to supplement the filter mechanism and the motivating system by creating an enabling environment of economic, social, and political values and institutions that influence individuals positively, in a manner that would be conducive to the realization of well-being in its comprehensive sense. This would bring into focus the need for socio-economic and political reform.

For example, if the need-fulfilment of all is accepted as a goal, and the operation of market forces does not automatically lead to this, then some arrangement may need to be made to realize this goal. If budgetary constraints prevent the state from playing an important role, then is it possible for the family and the society to share the burden? However, if the values or the structure of the families and the society have changed over time, making them unwilling or unable to share the burden, then is it possible for economics to not discuss the kind of socio-economic change that is necessary to realize its humanitarian goals. Its refusal to do so may be tantamount to giving blessings to the prevailing inequities. These might accentuate social unrest and tensions, which may lead ultimately to a decline of the society even in the material sense. Similarly, even if a society has values, but individuals are able to get away with dishonesty, bribery, and other unfair means of earning, there being no effective system for detecting and punishing the culprits, then such practices may become locked-in through the long-run operation of path dependence and self-reinforcing mechanisms. Everyone may then condemn the practice, but may not be able to eliminate it single-handedly by him or herself being honest and fair. Is it possible to eliminate the undesired practices by just giving sermons and not undertaking comprehensive reform through socio-economic and political restructuring'? If such restructuring is needed, could it be brought about without the state also playing a supportive role? Would it be possible for economics to abstain from discussing the kind of change that is needed and the role of the state in it?

If the mechanisms chosen by economics are not in conformity with the desired concept of well-being, or if the desired restructuring is not, or cannot be, brought about, then that kind of well-being may fail to be realized. Within this perspective, anything that prevents the kind of filtering, motivation, and restructuring that the desired well-being 
requires may be termed as distortion, and any use of resources that does not directly or indirectly contribute to, or that is in conflict with, goal realization may be considered unproductive, inessential, or wasteful. The role that the state plays in the economy may also be determined by the kind of filtering, motivation, and restructuring that are necessary for realizing its vision.

\subsection{ROLE OF THE WORLDVIEW}

The concept of well-being selected by economics as well as the filtering, motivation, and restructuring mechanisms adopted by it are determined essentially by its worldview. Some of the questions that the worldview tries to answer are about how the universe has come into existence, the meaning and purpose of human life, the ultimate ownership and objective of the limited resources at the disposal of human beings, and the rights and responsibilities of individuals and families towards each other and their physical and social environment.

The answers to these questions have a far-reaching influence on human thought and behaviour and lead to different theoretical frameworks and policy prescriptions. For example, if the universe is believed to have come into existence by itself, and human beings are not accountable to anyone, then they would be free to live as they please. Their purpose in life would be to serve their self-interest through the realization of maximum wealth and consumption. The measure of their well-being would, in this case, be the extent to which they attain bodily pleasures and sensual satisfactions. Survival of the fittest may perhaps be the most logical behaviour pattern. Value judgments may be unwarranted, and all the three mechanisms of filtering, motivation, and restructuring may be developed by human beings alone through reliance on their own reason and experience.

However, if all human beings have been created by the Supreme Being and the resources they have at their disposal are a trust from Him, then they would automatically become related to each other by a natural bond of brotherhood and also be accountable to Him. They would then not be absolutely free to do what they please, but would rather be expected to use the scarce resources and behave with each other and their environment in a way that would help realize the well-being of all individuals, irrespective of whether they are rich or poor, white or black, male or female, and children or adults. They would also be expected to ensure not only the realization of the material goals but also spiritual and humanitarian goals, particularly social harmony and absence of anomie. 
Revelation and reason would both in this case play an important role in filtering, motivation, and restructuring, and value judgments would not be out-of-bounds.

\subsection{THE METHOD}

The method of economics is also determined by its worldview. Linguistically, the term method refers to the rules and procedures of a discipline followed in a certain logical order to achieve a desired end (Blaug, 1980, p. xi; Caws, 1967, p. 339). Essentially, what the method does is to provide criteria for the acceptance or rejection of certain propositions as a part of the discipline (Blaug, 1980, p. 264; Machlup, 1978, p. 54). The steps taken and the criteria for acceptance or rejection thus depend, as Caws (1967, p. 339) has rightly indicated, on the end sought.

If survival of the fittest is an acceptable behaviour pattern, and if individuals are free to do what they wish in accordance with their preferences and their wealth, then the allocation and distribution brought about by market forces could not be questioned. There would be no point in talking about humanitarian goals. Economics would accept the status quo, pass no judgment on it, and make no policy recommendations to change it. Its method would then be just to describe (make positive statements about) how resources are actually allocated and distributed by the operation of market forces and to analyze, theoretically as well as empirically, the relationship among the different variables involved in such allocation and distribution, with a view to help make predictions about what may happen in the future. Economics would then be strictly a positive science with no normative role to play.

If, however, the purpose of economics is also to help realize the humanitarian goals, then the method may not be just to describe, analyze, and predict, but also to compare the actual results with the desired goals, to analyze the reasons for the gap between the two, and to show how the gap may be removed without unduly sacrificing individual freedom. Value judgments may not then be out-of-bounds. Because the purpose of revelation is to help in making such value judgments, it may also be welcome, and economics may then be based on both revelation and reason and experience. There may then be no justification for creating a watertight distinction between its positive and normative functions because both may be closely integrated and together constitute an indispensable part of its raison d'être. 


\subsection{THE RELEVANCE OF ISLAMIC ECONOMICS}

The vision, the mechanisms, and the method of economics are all, therefore, the logical outcome of its worldview. Even though none of the prevailing major worldviews is either totally materialist and hedonist nor totally humanitarian and spiritual, there are, nevertheless, significant differences among them in terms of the emphasis they put on the material or the spiritual goals. The greater the difference in the emphasis, the greater may be the difference in the economic disciplines of these societies. Feyerabend (1993) has frankly recognized this in the introduction to the Chinese edition of his thought-provoking book Against Method, by stating that 'First world science is only one science among many; by claiming to be more it ceases to be an instrument of research and turns into a (political) pressure group' (p. 3, parentheses are in the original). Even if the worldviews are the same, as is the case with institutional and conventional economics (Blaug, 1985, pp.708-11), which are believed by a number of economists to be complementary, the Nobel Laureate, Professor Douglass North, clearly stated: 'Introducing institutional analysis into static neoclassical theory entails modifying the existing body of theory. But devising a model of economic change requires the construction of an entire theoretical framework, because no such model exists' (North, 1990, p. 112).

However, if there is a substantial difference even in the worldviews and the visions, there is no reason why there cannot be greater differences in the disciplines. One discipline may just try to explain what exists, refuse to make value judgments, and not concern itself with socio-political change for realizing a certain vision of life. Another discipline may not find what is to be acceptable and aim at helping realize the desired social vision. It may not then be able to avoid a discussion of how, and through what process, the vision may be realized. This need not make the disciplines mutually exclusive. The rational and amicable discussion of different worldviews and disciplines may in fact promote greater depth and breadth in the analysis of both disciplines through cross-pollination, thus making the world richer and better off. Feyerabend (1993) is hence right in asserting that 'proliferation of theories is beneficial for science while conformity impairs its critical power. Uniformity also impairs the free development of the individual' (p. 5). 


\subsection{THE ISLAMIC WORLDVIEW}

This brings us to the very pertinent question of whether the worldview of Islamic economics is significantly different from that of conventional economics. Although there is a great deal that is common among the worldviews of most major religions of the world, particularly those of Islam, Christianity, and Judaism, it may not be possible to say the same about the worldviews of Islamic and conventional economics. The worldviews of both disciplines are radically different. The Islamic worldview is not secularist, value-neutral, materialist, or socialDarwinist. It is rather based on a number of concepts that strike at the root of these doctrines. It gives primary importance to moral values, human brotherhood, and socio-economic justice and does not rely primarily on either the state or the market for realizing its vision. It relies rather on the integrated roles of values and institutions, market, families, society, and the state, to ensure the realization of its vision of ensuring the well-being of all. It puts great emphasis on social change through a reform of the individual and his/her society, without which the market and the state could both perpetuate inequities.

The fundamental Islamic belief is that this universe and everything in it, including human beings, has been created by the One and the Only God. All human beings are His vicegerents and brothers unto each other. There is no superiority of one over the other because of race, sex, nationality, wealth, or power. Their sojourn in this world is temporary. Their ultimate destination is the Hereafter where they will be accountable before God. Their well-being in the Hereafter depends on whether or not they live in this world, and fulfil their obligations towards others, in a way that helps ensure the well-being of all individuals in society. ${ }^{3}$

One of the things that seriously affects the well-being of all individuals in society is the way the scarce resources, which are a trust from God, are used. God, the Creator and Owner of these resources, has provided certain values, rules of behaviour, or institutions, within the framework of which human beings are expected to use these resources and to interact with each other. These values have been given not just to any one specific group of human beings, but rather to all people at different times in history through a chain of His messengers (who were all human beings), including Abraham; Moses: Jesus; and, the last of them, Muhammad, peace and blessings of God be on them all. ${ }^{4}$ Thus according to Islam, there is a continuity and similarity in the value systems of all revealed religions to the extent to which the message has not been lost or distorted over the ages. 
The prophets did not, however, bring just the values. They also struggled to reform their societies. Socio-economic and political reform is, therefore, the major thrust of the Islamic message. To accept what is and not to struggle for the realization of the vision or what ought to be is a vote in favour of prevailing inequities and doing nothing to remove them. Such an attitude cannot be justifiable within the Islamic worldview. The mission of human beings is not just to abide themselves by the Islamic values, but also to struggle for the reform of their societies in accordance with these. This is what is meant by righteous living.

Righteous living would, it is believed, help promote a balance between individual and social interest and help actualize the maqasid al-Shari 'ah (the goals of the Shari'ah), or what may be referred to as the vision of Islam, two of the most important constituents of which are socioeconomic justice and the well-being of all life created by God. ${ }^{5}$ Injustice cannot but thwart the realization of true well-being, accentuate tensions and social unrest, discourage individuals from putting in their best, and thus retard development. However, whereas conventional economics assumes the prevalence of self-interested behaviour on the part of individuals, Islam does not assume the prevalence of ideal behaviour. It believes that, although some people may normally act in an ideal manner, the behaviour of most people may tend to be anywhere between the two extremes of selfishness and altruism and hence a constant effort (jihad) needs to be made on the part of both individuals and society for moral uplift.

Islam, however, rules out the use of force for moral uplift: 'There shall be no compulsion in religion' (al-Qur'an, 2:256), and 'Say that the Truth has come from your Lord: Whoever wishes may either believe in it or reject it' (al-Qur'an, 18:29). ${ }^{6}$ It rather lays stress on proper upbringing, creating conviction through logical reasoning and friendly dialogue (al-Qur'an, 16:125), and creating an enabling environment for motivating individuals to do what is right and to abstain from doing what is wrong. This is, however, not sufficient. It is also necessary to provide both material and spiritual incentives and deterrents to motivate individuals to do their best for their own good as well as that of others and to prevent them from causing harm to others. Smoothly functioning competitive markets, where people interact with each other in their self-interest, are necessary for ensuring maximum efficiency. However, although competition does help safeguard social interest to a certain extent, total reliance cannot be placed on it because some people may use unfair means to enrich themselves. Hence governments have tried to pass and enforce regulations. But regulations may not be possible without having a perception of what is the right thing to do. Therefore, once we regulate, 
we do not remain value-neutral. Moreover, it may not be realistic to depend primarily on regulations because regulations may be circumvented and need to be effectively enforced. The cost of enforcing them may be lower if there is some effective mechanism for self-enforcement.

This self-enforcement is believed to come from two sources. One of these is the innate goodness of the human being himself or herself. Within the framework of Islamic beliefs, people are good by nature because God has created them in His own image (al-Qur'an, 30:30). The individual does not necessarily always act in his self-interest. He/she also acts in the interest of others and even makes sacrifices for them under a feeling of moral obligation. However, because the individual is also free and his/her behaviour is not determined, he/she may or may not preserve his/her innate goodness and may act in ways that are against his/her nature. This may hurt him/her and his/her society. Therefore, it is necessary to provide incentives and deterrents as well as an enabling environment. The problem with a number of this-worldly incentives and deterrents is that they may be insufficient and may not even be justly implemented.

Therefore, the second source of self-enforcement is belief in the reward and punishment in the Hereafter. If I abstain from doing anything wrong and also sacrifice my material self-interest for the sake of others, I will improve my well-being in the Hereafter. The concept of Hereafter thus gives a long-term perspective to self-interest by extending it beyond a person's lifespan in this world. It is not possible for competition and government intervention to always motivate a person to do what is morally right and to abstain from what is morally wrong, to cooperate with others and to make sacrifices for them. Governments can try to ensure competition and to pass laws to safeguard social interest. However, there are so many clandestine ways of restraining competition and of cheating and exploiting others without being caught that it may be difficult for governments to succeed unless there is an inner urge on the part of operators in the market themselves to do what is right, to fulfil their contracts and other commitments faithfully, and not to try to undermine competition or resort to unfair means of earning. In the last analysis, therefore, it may not be possible to safeguard social interest effectively without the help of moral values and without creating an effective motivating force and a proper environment for their enforcement. This may reduce the burden on the government of safeguarding social interest. 


\subsection{THE HISTORICAL LINK}

Islamic economics had been developing gradually as an interdisciplinary subject in keeping with the Islamic worldview in the writings of Qur'an commentators, jurists, historians, and social, political, and moral philosophers. A large number of scholars, including Abu Yusuf (d. 798), alMas ‘udi (d. 957), al-Mawardi (d. 1058), Ibn Hazm (d. 1064), al-Sarakhsi (d. 1090), al-Tusi (d. 1093), al-Ghazali (d. 1111), al-Dimashqi (d. after 1175), Ibn Rushd (d. 1198), Ibn Taymiyyah (d. 1328), Ibn al-Ukhuwwah (d. 1329), Ibn al-Qayyim (d. 1350), al-Shatibi (d. 1388), Ibn Khaldun (d. 1406), al-Maqrizi (d. 1442), al-Dawwani (d. 1501), and Shah Waliyullah (d. 1762), made valuable contributions over the centuries. ${ }^{7}$ These scholars were not, however, specialists in economics. Strict compartmentalization of disciplines had not developed by then. They were masters of a number of different intellectual disciplines, and their contributions are, therefore, spread over a vast literature, some of which has been lost because of the vicissitudes of time and a wave of invasions particularly by the Mongols (Rosenthal, 1947, p. 19; Sarton, 1927, Vol. 1, p. 662). It was perhaps because of this multidisciplinary nature of their contributions that human well-being never got conceived as an isolated phenomenon dependent primarily on economic variables. It was seen as the end-product of a number of economic as well as moral, psychological, social, demographic, and political factors in such an integrated manner that it was not possible to realize overall human well-being without an optimum contribution from all. Justice occupied a pivotal place in this whole framework. This was to be expected because of its crucial importance within the Islamic worldview.

These diverse contributions over the centuries seem to have reached their consummation in Ibn Khaldun's (n.d.) Muqaddimah, or Introduction to Histon, where he tried to analyze the closely interrelated roles of moral, psychological, political, economic, social, demographic, and historical factors over a period of three generations, or 120 years, in the rise and fall of a dynasty (dawlah) or civilization (umran). His analysis was thus not static and was not based on only economic variables. It was, rather, dynamic and multidisciplinary. The need for such an analysis was felt by him because he lived at a time (1332-1406) when the Muslim civilization was already in a process of decline and, as a conscientious Muslim, he was keen to see a reversal of the tide. However, this is not all that he did. The Muqaddimah also contains a considerable discussion of economic principles, a significant part of which is undoubtedly Ibn Khaldun's original contribution to economics. ${ }^{8}$ 
His contributions did not, unfortunately, get fertilized and developed further in the Muslim world. As he rightly theorized himself, sciences progress only when a society is itself progressing (Ibn Khaldun, n.d., p. 434). This theory has become clearly upheld by Muslim history. Sciences progressed rapidly in the Muslim world from the middle of the 8th century to the middle of the 12th century. The development continued at a decelerated pace for two more centuries (Sarton, 1927-1948; Sezgin, 1983 and ff.). Thereafter, there appeared a brilliant star only once in a while on an otherwise unexciting firmament. Economics was no exception. It also continued to be in a state of limbo in the Muslim world. No major contributions were made after Ibn Khaldun, except by a few isolated luminaries such as al-Maqrizi (d. 1442), al-Dawwani (d. 1501), and Shah Waliyullah (d. 1762).

Consequently, whereas conventional economics became a separate scientific discipline in the West in the 1890s after the publication in 1890 of Alfred Marshall's great treatise, Principles of Economics (Schumpeter, 1954, p. 21) ${ }^{9}$ and has continued to develop since then, Islamic economics remained primarily an integral part of the unified social and moral philosophy of Islam until the Second World War. The independence of most Muslim countries after the War and the need to develop their economies in a way that would help realize the Islamic vision has given boost to the reemergence of Islamic economics. This need not give anyone the impression that the attempt is to bypass the good and valuable analytical work done by conventional economics and its offshoots. It would be difficult not to agree with Blaug (1980) when he said that 'any methodological prescription that amounts to wiping clean the entire slate of received economics and to starting all over again from scratch may be dismissed out of hand as self-defeating' (p. 121).

\subsection{ACHIEVEMENTS, SHORTCOMINGS AND FUTURE PROSPECTS}

Islamic economics has so far, however, been able to scratch only the surface of what Ibn Khaldun's multidisciplinary dynamics entails. Greater emphasis has been laid so far on explaining what the ideal Islamic economic system is, how it differs from socialism and capitalism, and why the operation of markets within the framework of the Islamic worldview would help minimize some of the glaring inequities of the market system and exert a positive impact on the realization of overall human well-being without excessive reliance on the state. Most of the discussion is, however, of a normative nature - how all economic agents 
(individuals and households, firms, altruistic organizations, markets and governments) are expected to behave in the light of Islamic norms. This has been accompanied by some sporadic historical data to show that the system has actually been in existence for at least short periods at different times in Muslim history and that this has produced positive results. This was natural and in fact necessary. Economics is so closely related to the worldview and the economic system of a society that without clarity about these, Islamic economics may have groped in the dark for the direction in which to proceed. ${ }^{10}$

The other area where substantial, although still far from adequate, literature has become available is Islamic finance. An effort has been made to show why an economy that relies less on credit and more on equity may be superior in its overall performance to the one that relies substantially on credit, particularly on short-term credit (Mills and Presley, 1999, pp. 58-72 and 114-20; Chapra, 1985, pp. 107-45; 1992, pp. 327-34). Some progress has also been made in macroeconomics. There has been a considerable discussion of the Islamic vision (Ahmad and Awan, 1992; Khan, 1994). There is, however, no theoretical macroeconomic model that would show how the Islamic values and institutions, and different sectors of the economy, society and polity would interact to help realize the vision. An appropriate macroeconomic policy package has hence not developed. The field where very little progress has been made is microeconomics. It has not been possible to establish the relationship among the macroeconomic goals and the behaviour of different economic agents and the kind of socio-economic and political reform that the realization of goals may require. Yalcintas (1986) is perhaps right in stating that 'Construction of microeconomic theory under the Islamic constraints might be the most challenging task before Islamic economics' (p. 38).

Although there is undoubtedly some merit in showing how the injection of a moral dimension into economics might help realize the Islamic vision without excessive dependence on the state, such a discussion does not take us very far. Due to centuries of decline, disintegration, and lack of proper education, Islamic values are not reflected either in individual or social behaviour or in the prevailing legal, social, political, and economic institutions of Muslim countries. There is a great deal of deviation from Islamic norms. A number of morally wrong practices, such as dishonesty, corruption, extravagance, wastefulness, and lack of punctuality and conscientiousness have become securely locked-in through the long-run operation of path dependence and self-reinforcing mechanisms. The deviation is taking a heavy toll of justice, development, and general well-being (see Chapra, 1992, pp. 251-338). The task of 
Islamic economics does not, therefore, get fully accomplished if it does not show the causes of this deviation. Other societies have translated their values into formal institutions in spite of an external secularist and value-neutral stance (Organisation for Economic Co-operation and Development, 1996). They have formulated a legal framework and a proper code of conduct for government officials and put in place mechanisms for transparency, rule of law, public accountability, and protection of whistle-blowers. They have also created sufficient checks and balances and adopted measures that would make it difficult for violators to get away unscathed. Muslim countries have generally lagged behind here. The question is why. It may not be possible to answer this question without also injecting psychological, social, political, and historical dimensions into the analysis. One of the major reasons for the Muslim malaise may be the failure of the political system. There is hardly any Muslim country where there is a truly democratic government, accountable to the people, where the press is really free, where the courts are independent of political interference, and where the law of the land gets applied fairly and impartially to all, irrespective of their wealth and power. This is in clear violation of the Islamic norms related to the polity. The result is that senior government functionaries are able to get away with corruption, inequities, and incompetence. This frustrates the effective and impartial operation of incentives and deterrents and creates a favourable climate for the general violation of Islamic norms. The country's resources do not, therefore, get used efficiently and equitably for the well-being of the people. In addition, there is a glaring omission in Islamic economics of a scientific analysis of some of the crucial problems of Muslim countries, including budgetary and balance of payments deficits, high debt-servicing burden, low levels of saving, investment and real growth, high rates of inflation and unemployment, extreme inequalities of income and wealth, and miserable socioeconomic condition of the poor.

There could be no escape from what Ibn Khaldun (1950) did for his society - adopting a multidisciplinary approach to find out the causes of the various problems and suggesting, in the light of such analysis, a comprehensive, well-integrated, and practical reform program. Within the framework of his multidisciplinary dynamic model, concentrating only on moral or economic variables may not be able to take the Muslim world very far on the path of development with justice.

Islamic economics also needs to collect reliable data on a number of important economic variables. Without knowing the actual position and the reasons for it, it may not be possible to prepare a well-conceived 
program for social, economic, and political change. Data create transparency and reveal the true picture, which some governments do not welcome. Hence one of the essential prerequisites for reform is the collection and publication of necessary data and their scientific analysis. Missing in particular are data on distribution of income and wealth, extent of need-fulfilment, and nature and quality of life, particularly of the downtrodden people. Without such data, it is not possible to know the degree of equity prevailing in the allocation and distribution of resources, which is the most crucial criterion for judging the Islamization of a Muslim economy. There are also inadequate data about government revenues and expenditures, consumption, saving and investment behaviour of individuals and different sectors of the population, employment and unemployment, bonded, female and child labour, wages and salaries, working conditions, work habits, and productivity, along with a rational explanation for the deviation from Islamic norms. Once this is done, it may be possible for Islamic economics to do a more meaningful job of analyzing the impact that the introduction of Islamic values and institutions may have on aggregate consumption, saving and investment. economic growth and stability, and distribution of income.

The practical wisdom of Islamic economics has thus been unable to come to grips with the task of explaining the rise and fall of Muslim economies in the past, the lag between Islamic norms and the actual behaviour of economic agents, and the causes of problems faced by Muslim countries. It has been unable to suggest a balanced package of policy proposals in the light of Islamic teachings to enable Muslim countries to perform the difficult task of reducing their imbalances and simultaneously actualizing the Islamic vision. Moreover, its theoretical core has also thus far been unable to come out of the straitjacket of conventional economics, which takes into account primarily the economic variables that are measurable and generally avoids a discussion of the complex historical interplay of moral, psychological, economic, social and political factors. Islamic economics has thus 'failed to escape the centripetal pull of Western economic thought, and has in many regards been caught in the intellectual web of the very system it set out to replace' (Nasr, 1991, p. 388). It is thus unable to explain the difference in the performance of various societies with respect to overall human well-being.

The potential is, however, great but the expectations for the near future should not be pitched at a very high level. It may not be possible to raise Muslim societies, at least in the near future, to the high spiritual level that Islam demands and that Muslim economists assume in their analysis. Moreover, the performance of all the functions that are expected from 
Islamic economics may not be immediately feasible because of the lack of resources and political support, the non-availability of data, and the difficulty of measuring a number of the socio-economic and political variables that need to be incorporated into the models. It is possible that even after a great effort, the achievements may not be significantly great. The discipline will mature over time after passing through an evolutionary process. It has, fortunately, the advantage of benefiting from the tools of analysis developed by conventional, social, humanistic, and institutional economics as well as other social sciences.

\section{ACKNOWLEDGEMENT}

I gratefully thank $\mathrm{Mr}$ Mobin Ahmad for the secretarial assistance provided by him in the preparation of this chapter.

\section{NOTES}

1. It may be desirable to be clear about the difference between the terms distribution and redistribution. Distribution refers to the allocation of resources that takes place automatically through the operation of market forces. However, when a society uses extramarket or other nonmarket processes to change that distribution in accordance with the concept of justice embodied in its worldview, it is referred to as redistribution.

2. The literature on the determinants of human well-being has been growing rapidly. For a survey of this literature, see David Myers (1993).

3. For greater detail on the fundamentals of the Islamic worldview, see Chapra (1992), pp. 201-12.

4. The Qur'an does not make any mention of the prophets sent by God to people other than those in the Middle East. Their names were not familiar to them, and the Qur'an is not intended to be an encyclopedia. However, it states clearly that 'And indeed We have sent Our Messengers to every community in every period' (al-Qur'an, 16:36). 'And We sent Messengers before you; some of them We have mentioned to you, while some others We have not mentioned' (al-Qur'an, 40:78).

5. For a brief discussion of the vision of Islam or the maqasid al-Shari 'ah, see Chapra (1992), pp. 7-9. There has been a substantial discussion of the maqasid al-Shari"ah in the fiqh literature, some of the most prominent exponents being al-Matridi (d. 945), al-Shashi (d. 975), al-Baqillani (d. 1012), al-Juwayni (d. 1085), al-Ghazali (d. 1111), Fakhr al-Din al-Razi (d. 1209), al-Amidi (d. 1234), 'Izz al-Din 'Abd al-Salam (d. 1262), Ibn Taymiyyah (d. 1327), and al-Shatibi (d. 1388). For a modern discussion of these, see Masud (1977); al-Raysuni (1992), pp. 25-55; and Nyazee (1994), pp. 189-268.

6. The Qur'an repeats the same message in a number of other places. For example, 'Are you going to compel people to believe' (al-Qur'an, 10:99) and 'You are not there to force them to believe. Exhort through the Qur'an whoever takes heed of the Warning' (al-Qur'an, 50:45). 
7. For a brief account of some of these contributions, see De Shmogyi (1965), Islahi (1996), Mirakhor (1987), Siddiqi (1992), and Spengler (1964).

8. See also Muqaddimah's translation under Rosenthal (1967) and selections from it under Issawi (1950). For details of Ibn Khaldun's multidisciplinary dynamic model, see Chapter 5 of my forthcoming book, The Future of Economics: An Islamic Perspective (Leicester, UK: The Islamic Foundation).

9. According to Blaug (1985, p. 3), economics became an academic discipline in the 1880 s.

10. According to Zarqa (1986), Islamic economics is "the "economic system", on the one hand, and "the economic analysis thereof", on the other' (p. 52).

\section{REFERENCES}

Ahmad, A., and Awan, K.R. (eds) (1992), Lectures on Islamic Economics (Jiddah: IDB).

Blaug, M. (1980), The Methodology of Economics or How Economists Explain (Cambridge: Cambridge University Press).

Blaug, M. (1985), Economic Theory in Retrospect, 4th edn (Cambridge: Cambridge University Press).

Brzezinsky, Z. (1995), Out of Control: Global Turmoil on the Eve of the 21st Century (New York: Touchstone Books).

Caws, P. (1967), Scientific method. In P. Edwards (ed.), The Encyclopedia of Philosophy (London: Macmillan), pp. 339-43.

Chapra, M.U. (1985), Towards Just Monetary System (Leicester, UK: The Islamic Foundation).

Chapra, M.U. (1992), Islam and the Economic Challenge (Leicester, UK: The Islamic Foundation).

Chapra, M.U. (1996), What is Islamic Economics? (Jeddah: IRTI).

De Shmogyi, J.N. (1965), Economic theory in classical Arabic literature. Studies in Islam (January), 1-6.

Easterlin, R. (1973), Does money buy happiness? The Public Interest (Winter).

Easterlin, R. (1995), Will raising the incomes of all increase the happiness of all? Journal of Economic Behavior and Organization, 27, 35-48.

Feyerabend, P. (1993), Against Method, 3rd edn (London: Verso).

Hodgson, M.G.S. (1977), The Venture of Islam: Conscience and History in a World Civilization (Chicago, IL: University of Chicago Press).

Ibn Khaldun (n.d.), 'Abd al-Rahman. Muqaddimah (Cairo: AI-Maktabah al-Tijariyyah al-Kubra).

Islahi, A.A. (1996), History of Economic Thought in Islam (Aligarh, India: Department of Economics, Aligarh Muslim University).

Islamic Research and Training Institute, Islamic Development Bank (1986), Problems of Research in Islamic Economics (Jeddah: Islamic Research and Training Institute).

Issawi, C. (1950), An Arab Philosophy of History. Selections from: the Prolegomena of Ibn Khaldun of Tunis (1332-1406) (London: John Murray).

Khan, M.F. (1994), Essays in Islamic Economics (Leicester, UK: The Islamic Foundation). 
Machlup, F. (1978), Methodology of Economics and Other Social Sciences (New York: Academic Press).

Masud, M.K. (1977), Islamic Legal Philosophy: A Study of Abu Ishaq al-Shatibi's Life and Thought (Islamabad: Islamic Research Institute).

Mills, P.S. and Presley, J.R. (1999), Islamic Finance: Theory and Practice (London: Macmillan Press).

Mirakhor, A. (1987), The Muslim scholars and the history of economics: A need for consideration. American Journal of Islamic Social Sciences (December), 245-76.

Myers, D.G. (1993), The Pursuit of Happiness. Who is Happy and Why? (New York: Avon).

Nasr, S.V.R. (1991), Islamisation of knowledge: a critical overview. Islamic Studies (Autumn), 30, 3, 387-400.

North, Douglass C. (1990), Institutions, Institutional Change, and Economic Performance (Cambridge: Cambridge University Press).

Nyazee, I.A.K. (1994), Theories of Islamic Law. The Methodology of Ijtihad (Islamabad: IIIT).

OECD (1996), Ethics in the Public Service. Current Issues and Practice (Paris: OECD, Public Management Occasional Papers, No. 14).

Oswald, A.J. (1997), Happiness and economic performance. Economic Journal (November), 815-31.

Oswald, A.J., Frank, R.H. and Ng, Y.-K. (1997), Economics and happiness. Economic Journal (November), 1812-58.

Raysuni, A. (1992), al-Nazariyyah al-Maqasid 'Inda al-!mam al-Shatibi, 2nd edn (Riyadh: Al-Dar al-Alamiyyah lil Kitab al-Islami).

Rosenthal, F. (1947), The technique and approach of Muslim scholarship. Analecta Orientelia (Rome: Pontificam Institutum Biblicum), 24.

Rosenthal, F. (1958), Ibn Khaldun. The Muqaddimah, An Introduction to History, 1st edn (2nd edn 1967; 3 volumes) (London: Routledge and Kegan Paul).

Sarton, G. Introduction to the History of Science. (3 volumes issued between 1927 and 1948, the 2nd and 3rd in two parts each) (Washington: Carnegie Institute).

Schumpeter, J.A. (1954), History of Economic Analysis, Elizabeth B. Schumpeter (ed.) (New York: Oxford University Press).

Sezgin, F. (1983), Tarikh al-Turath al-'Arabi [History of Arab Legacy] (First volume, followed by other volumes in later years) (Mahmud Fahmi Hijazi, Trans.) (Riyadh: Imam Muhammad ibn Saud Islamic University).

Siddiqi, M.N. (1992), History of Islamic economic thought. In Ahmad and Awan (1992), pp. 69-90.

Spengler, J. (1964), Economic thought of Islam: Ibn Khaldun. Comparative Studies in Society and History, 6, 268-306.

Yalcintas, N. (1986), Problems of research in Islamic economics: General background. In Islamic Research and Training Institute (1986), pp. 23-41.

Zarqa, M.A. (1986), Problems of research in the theory of Islamic economics: Suggested solutions. In Islamic Research and Training Institute (1986), pp. 52-63. 